\title{
The Bhaduri-Marglin post-Kaleckian model in the history of distribution and growth theories: an assessment by means of model closures*
}

\author{
Eckhard Hein \\ Berlin School of Economics and Law and Institute for International Political Economy (IPE), Berlin, \\ Germany
}

\begin{abstract}
Starting from a review of the main strands of orthodox and heterodox distribution and growth models and their distinguishing features, with the post-Kaleckian Bhaduri and Marglin (1990) (and Kurz 1990) model as a specific but highly flexible variant of heterodox distribution and growth theories, we develop a simple modelling framework in which we can treat these different theories as different variants of model closure. In a simple closed private one-good economy model, each theory is presented drawing on the relationship between the rate of profit and the rate of growth, as well as on the consideration of one major adjusting variable allowing for the convergence of the endogenous variables of the model to their equilibrium values. This allows for a systematic comparison of exogenous and endogenous variables, of the 'logic' or the chain of causalities in each of the approaches, and of the generation of the long-run equilibrium positions of the system. It is finally shown that the post-Kaleckian model is able to cover many but not all of the results generated by the old neoclassical growth model, new neoclassical growth theories, classical-Marxian distribution and growth approaches, and post-Keynesian Kaldor-Robinson and Kalecki-Steindl distribution and growth theories.
\end{abstract}

Keywords: distribution, growth, model comparison, Bhaduri-Marglin model

JEL codes: E21, E22, E25, O41

\section{INTRODUCTION}

'Particular models such as that of 'cooperative capitalism' enunciated by the left Keynesian social democrats, the Marxian model of 'profit squeeze' or even the conservative model relying on 'supply-side' stimulus through high profitability and a low real wage, fit into the more general Keynesian theoretical scheme. They become particular variants of the theoretical framework presented here.'

Bhaduri and Marglin (1990, p. 388, emphasis in the original)

* This paper is based on my recent book on Distribution and Growth after Keynes: A PostKeynesian Guide (Hein 2014). For helpful comments and suggestions I would like to thank Daniel Detzer, Marc Lavoie, and an anonymous referee. And for editing assistance I am grateful to Luisa Bunescu. Remaining errors are mine, of course. 
This is how Bhaduri and Marglin summarise what they have achieved and contributed in their seminal 1990 Cambridge Journal of Economics paper. Similar conclusions could have been drawn by Kurz (1990), who provided a similar model framework to Bhaduri and Marglin's (1990), deriving different regimes - and furthermore discussing different forms of technical progress within this framework. We have termed this modelling approach, generating the potential of different regimes of demand and growth in a closed economy model without saving out of wages, the 'post-Kaleckian model' (Hein 2014, ch. 6). It is distinguished from the 'neo-Kaleckian model' based on the works of Rowthorn (1981) and Dutt (1984; 1987), 'only' generating 'stagnationist', 'underconsumptionist' or 'wage-led' regimes in its basic version, that is, a depressing effect of redistribution at the expense of the wage share on demand, capacity utilisation and growth. ${ }^{1}$

Since the 1980s/1990s, the basic versions of both variants of the Kaleckian model have been extended to include all sorts of real-world features: saving out of wages, international trade, endogenous productivity growth, interest and credit, as well as issues of 'financialisation', among others, as has been reviewed by Blecker (2002), Hein (2014, chs 7-10) and Lavoie (2014, ch. 6), for example. And the 'post-Kaleckian' model variant has provided the theoretical foundations for extensive empirical and econometric work, in order to identify the specific regime for specific countries in specific time periods, starting with the work by Bowles and Boyer (1995) and proceeding up to the latest contributions by Onaran and Galanis (2014) and Hartwig (2014), among several others (see Hein 2014, ch. 7 for a review).

Here we will neither add further features to the post-Kaleckian model nor contribute to the empirical work based on this model. ${ }^{2}$ Our concern is more modest and rather didactic and pedagogical. We attempt to contextualise and situate the Bhaduri and Marglin (1990) and Kurz (1990) model in the history of distribution and growth theories and to compare it in a systematic way to other approaches using the method of model closures.

Of course, using model closures in order to compare different approaches in the area of distribution and growth has been around for a while. As acknowledged by Marglin (1984a, p. 530), Sen (1963) introduced this concept, ${ }^{3}$ comparing neoclassical and neo-Keynesian approaches - the latter are today rather termed post-Keynesian models in the tradition of Kaldor and Robinson (Hein 2014, ch. 4). Marglin (1984a; 1984b) has used this method in order to compare neoclassical, neo-Marxian and neo-Keynesian (that is, post-Keynesian) models. Amadeo (1986) has compared a Marxian, a post-Keynesian Kaldor-Robinson and a Kaleckian case in a unified framework. Similarly and much more elaborately and extensively, Dutt (1990) has provided a comparison of neoclassical, neo-Marxian, post-Keynesian Kaldor-Robinson (which he calls neo-Keynesian) and Kalecki-Steindl approaches. The latter is in essence what we have termed the neo-Kaleckian model (Hein 2014, ch. 6). The post-Kaleckian approach based on Bhaduri and Marglin (1990) and Kurz (1990) has not been included in this kind of literature so far, and we will thus fill this gap here. But before doing so in Section 3 of the paper, we will briefly review the major distinguishing features of the main approaches towards (functional)

1. Including international trade also allows for profit-led demand and growth in an otherwise neo-Kaleckian framework, as Blecker (1989) has shown even before Bhaduri and Marglin (1990).

2. For most recent assessments of the empirical literature and some of the controversies, see Blecker (2016).

3. I am grateful to an anonymous referee for drawing my attention to this fact. 
income distribution and growth in Section 2. The final Section 4 will summarise and conclude.

\section{THE DISTINGUISHING FEATURES OF ORTHODOX AND HETERODOX THEORIES OF DISTRIBUTION AND GROWTH}

From the current perspective, the theories of distribution and growth can be broadly separated into orthodox approaches and heterodox approaches. Here, we are only interested in the basic structures of the models, the main chains of causalities and the determinations of long-run growth equilibria or trends.

The orthodox approaches contain the neoclassical microeconomic theory of distribution, as included in the general equilibrium theory going back to Walras (1954), the neoclassical macroeconomic theory of distribution, based on Wicksell (1893) and Clark (1899), and then in particular the old neoclassical growth models proposed by Solow (1956) and Swan (1956), and finally the new neoclassical growth theories starting with works of Romer (1986) and Lucas (1988), and nowadays mainly included in mainstream textbooks and taught in mainstream academic programmes. ${ }^{4}$ In principle, the neoclassical approach explains both income distribution and growth in a unified and integrated framework taken from its foundations in allocation theory based on 'first principles'. These are given production technologies (that is, production functions), given preferences (that is, utility functions), given initial endowments of economic agents, and the assumption of strictly utility- and profit-maximising behaviour of economic agents in perfectly competitive markets. Assuming marginal productivity remuneration of the factors of production, the technology of production thus determines the income shares of the factors of production.

When it comes to growth, in the old neoclassical growth models à la Solow (1956), flexible factor prices and smooth substitution between capital and labour guarantee the adjustment towards an exogenously given full employment equilibrium growth rate, the 'natural rate of growth', determined by non-explained rates of labour-force growth and technical progress. In the modern version of neoclassical growth theory, that is, in the new neoclassical or endogenous growth theory, productivity growth and hence the natural rate of growth are determined endogenously in a way that is consistent with neoclassical first principles. In this approach it is technology, either externalities of the production process, or the technologies applied in the purposeful generation of growth-enhancing human capital or $\mathrm{R} \& \mathrm{D}$, as well as preferences, in particular the time preference of households regarding present and future consumption, that determine productivity growth and, with a given rate of labour-force growth, thus the natural rate of growth.

Assuming Say's law to hold in the long run, old and new neoclassical distribution and growth models ignore the Keynesian problem of the non-neutrality of money and the importance of effective demand for long-run growth. Furthermore, they have to face the critique of the 'Cambridge controversies in the theory of capital', questioning the very existence of uniquely downward-sloping factor demand curves in price-quantity space and the smooth substitution of factors of production guided by relative factor prices in a more than one-good economy (Harcourt 1969; Lazzarini 2011; Hein 2014, ch. 3, sec. 6).

4. See, for example, Barro and Sala-i-Martin (2004) and Aghion and Howitt (2009), and, for a simplified overview, Hein (2014, ch. 3). 
Based on this critique, heterodox approaches, like classical and Marxian theories, as well as different post-Keynesian approaches, contain a degree of freedom in the determination of relative prices and thus in functional income distribution, which can be closed by different socioeconomic distribution theories. Furthermore, income distribution, capital accumulation and growth are interrelated, albeit in different ways.

The classical authors, such as Adam Smith (1776) and David Ricardo (1817), as well as Karl Marx $(1867 ; 1885 ; 1894)$ assume that functional income distribution is determined by socio-institutional factors and power relationships determining a conventional real wage rate. For a given production technology, the rate of profit then becomes a residual variable. As an alternative based on Sraffa's (1960, p. 33) ideas, some neo-Ricardian authors, such as Panico (1985) and Pivetti (1991), have proposed to take the rate of profit as being determined by the monetary interest rates, making the real wage rate the residual variable. With functional income distribution determined in either way, the rate of profit, together with capitalists' propensity to save and to accumulate, determines the long-run equilibrium rates of capital accumulation and growth. ${ }^{5}$ In this approach, the validity of Say's law in Ricardo's version is assumed: ${ }^{6}$ profits saved are completely used for investment and accumulation, so that no problems of effective demand for the economy as a whole arise in long-run growth. However, for the classical authors and Marx, this does not mean that the growth path is characterised by full employment. On the contrary, unemployment is considered to be a persistent feature of capitalism, constraining distribution claims of workers and thus providing the conditions for positive profits, capital accumulation and growth. Furthermore in this perspective, capital accumulation feeds back on the rate of profit in the long run, and causes a tendency of the rate of profit to fall. This is either due to the specific nature of technical progress causing a falling productivity of capital (Marx's notion of a rising 'organic composition of capital'), or it is caused by the falling marginal productivity of land which may not be compensated for by productivityenhancing technical progress (Ricardo).

From a (post-)Keynesian perspective, this classical and orthodox Marxian approach, of course, suffers from the assumption of the long-run neutrality of money and from the lack of any role for effective demand in long-run growth theory. Therefore, the first generation of post-Keynesian distribution and growth theories put forward by Nicholas Kaldor $(1957 ; 1961)$ and Joan Robinson $(1956 ; 1962)$ have relied on John Maynard Keynes's (1936 [1973]) and Michal Kalecki's (1939; 1969) 'principle of effective demand' and have attempted to extend it to the long period, and hence to growth and distribution issues (Hein 2014, ch. 4). From this perspective, in a monetary production economy, investment by firms is independent of prior saving and is the driving force of the growth process, because firms have access to finance independently of any prior saving in the economy. For the macro-economy, saving will have to adjust to investment, and since the post-Keynesian approach by Kaldor and Robinson assumes the long-run full or normal utilisation of productive capacities given by the capital

5. For an introduction to the classical approach to distribution and growth, see Pasinetti (1974, ch. 1), Harris (1987) and Kurz and Salvadori (2003), and for an overview of Marxian theories, see Shaikh (1978).

6. The validity of Say's law, however, is not accepted by all classical economists, as Sowell (1972) has pointed out. Also Marx's theory allows for an interpretation, in which aggregate demand, finance, credit and interest rates matter for the determination of long-run accumulation and growth, as for example Argitis (2001) and Hein (2006) have discussed. 
stock, ${ }^{7}$ this adjustment has to take place through changes in income distribution, assuming a higher propensity to save out of profits than out of wages. And this will only happen if prices in the goods markets are more flexible than nominal wages in the labour market, such that a change in investment and aggregate demand triggers a change in functional income distribution. The causality known from the classicals and Marx is thus reversed: the rate of profit is determined by the rate of accumulation and growth, as well as by the propensities to save out of profits and out of wages.

Obviously, the assumption of long-run growth with a normal or full rate of capacity utilisation and the related requirements of goods market prices to be more flexible than nominal wages in the long run, in order to generate the required redistribution and adjustment of saving to investment, poses some problems. First, it is not clear why, in organised oligopolistic goods markets, price reactions should be speedier than quantity responses, in particular during periods of shrinking demand. Second, even if prices were highly flexible, it is not clear why nominal wages should be more rigid in the long run, and, in particular, why workers should accept a lower real wage rate or wage share whenever capital accumulation accelerates. Of course, Robinson (1962, pp. 58-59) discussed the exceptional case of the 'inflation barrier', in which there is a tendency of the real wage rate to be forced below some conventional or target level, and workers start to resist, generating a price-wage-price spiral. However, it remains unclear why workers should accept a lower real wage rate at any level of the wage rate.

Alternatively, in the second generation of post-Keynesian models based on Michal Kalecki's $(1954 ; 1971)$ and Josef Steindl's (1952) works, the independence of capital accumulation of firms from saving at the macroeconomic level is connected with a determination of income distribution by relative economic powers of capital and labour, mainly through firms' mark-up pricing - on constant unit labour costs up to full capacity output - in imperfectly competitive goods markets. Functional income distribution and hence the profit share are thus explained by relative economic powers of capital and labour affecting the mark-up in firms' pricing, and the rate of capacity utilisation - as an accommodating variable in the long run - is determined by aggregate demand growth and hence by capital accumulation and consumption. ${ }^{8}$

The effects of distributional changes on equilibrium capacity utilisation and growth mainly depend on the relative weights of demand/utilisation and profitability determinants in the investment functions. The neo-Kaleckian model based on the works of Rowthorn (1981) and Dutt $(1984 ; 1987)$ contains a strong accelerator effect of demand and no direct effect of profitability in the investment function. In its closed economy version without saving out of wages it generates uniquely depressing effects of redistribution at the expense of the wage share on the rates of capacity utilisation, capital accumulation, growth and profit. The post-Kaleckian model, based on the works of Bhaduri and Marglin (1990) and Kurz (1990), however, also contains a direct profitability effect in the investment function. Therefore, its closed-economy version without saving out of wages is able to generate different regimes of demand and growth, hence positive or negative effects of a lower wage share on capacity utilisation, capital accumulation, growth and the rate of profit, depending on the relative weights of

7. Kaldor even assumed full employment in his early essentially one-sector equilibrium growth models, which he abandoned in his later work, that is, in Kaldor (1966).

8. The treatment of the rate of capacity utilisation as a long-run endogenous variable has been criticised and debated for a while. For recent reviews, see Hein et al. (2011; 2012), Hein (2014, ch. 11) and Lavoie (2014, ch. 6, sec. 5). 
accelerator and profitability terms in the investment function and on the differential in the propensity to save from profits and from wages.

\section{A SYSTEMATIC COMPARISON BY MEANS OF MODEL CLOSURES}

Let us now compare the basic features of each of the approaches outlined above making use of a very simple model and then apply different closures, according to the different theories. In essence we will start with two equations for the basic model, and will then add four equations for each approach, in order to close the model. Each approach can then be described graphically in a two-quadrant system by the relationship between the rate of growth and the rate of profit, on the one hand, and by an endogenous variable adjusting the rate of profit to its long-run equilibrium value, on the other hand.

\subsection{The basic model}

We assume a closed economy without a government sector, which is composed of two classes, workers and capitalists. Workers offer labour power to capitalists and receive wages, which they use in order to purchase consumption goods. We assume a classical saving hypothesis so that there is no saving from wages. Capitalists own the means of production and receive profits, which are partly consumed and partly saved - buying assets issued by the corporate sector and thus the capitalists themselves, or depositing parts of the profits with the financial sector, which is also owned by the capitalists and not explicitly modelled here. Capitalists control the capital stock, hire labour, organise the production process, and decide about investment and thus the expansion of the capital stock. For the latter they draw on their own means of finance, issue stocks or corporate bonds or draw on credit endogenously generated and granted by the financial sector. By assumption, all these transactions take place within the capitalist class and are not modelled here.

In our model economy, a homogeneous output $(Y)$ is produced combining direct labour and a non-depreciating capital stock in the production process. The homogeneous output can be used for consumption and investment purposes. For the sake of simplicity we refrain from the consideration of overhead labour and depreciation of the capital stock, as well as raw materials and intermediate products. The rate of profit $(r)$ relating the flow of profits $(\Pi)$ to the nominal capital stock $(p K)$ can be decomposed into the profit share $(h)$, relating profits to nominal income $(p Y)$, the rate of capacity utilisation $(u)$, relating actual output to potential output given by the capital stock $\left(Y^{p}\right)$, and the inverse of the capital-potential-output ratio $(v)$, relating the capital stock to potential output:

$$
r=\frac{\Pi}{p K}=\frac{\Pi}{p Y} \frac{Y}{Y^{p}} \frac{Y^{p}}{K}=h u \frac{1}{v} .
$$

Our assumption regarding saving translates into the following saving rate $(\sigma)$, which relates the flow of total saving $(S)$ to the value of the capital stock:

$$
\sigma=\frac{S}{p K}=\frac{s_{\Pi} \Pi}{p K}=s_{\Pi} r=s_{\Pi} h u \frac{1}{v}, \quad 0<s_{\Pi} \leq 1 .
$$

With zero saving out of wages, the saving rate is determined by the propensity to save out of profits $\left(s_{\Pi}\right)$ and by the profit rate, respectively the components of the profit rate 
from equation (1). It should be noticed that in the neoclassical growth theory there is no distinction between saving out of profits and saving out of wages, but just an average propensity to save out of income. With our classical saving hypothesis, the average propensity to save out of income $(s)$ is given by $s=s_{\Pi} h$, and it will hence rise with an increase in the propensity to save out of profits and with the profit share.

\subsection{The old neoclassical closure}

Starting with the old neoclassical growth model in the tradition of Solow (1956) and Swan (1956), we obtain the following closure. In long-run equilibrium, capacity utilisation is at its normal or target rate $\left(u_{n}\right)$. Profit-maximising firms use the capital stock at the optimal rate - and labour is fully employed through a flexible real wage rate in the labour market:

$$
u=u_{n} .
$$

Functional income distribution, and thus the profit share in the neoclassical model are determined by the production technology, assuming marginal productivity remuneration. With a Cobb-Douglas production function, the profit share is given by the output elasticity of capital:

$$
h=\bar{h} \text {. }
$$

From equations (1), (3n) and (4n), the capital-potential-output ratio remains as a variable which may adjust the profit rate to its value required by the growth equilibrium. The latter is given by the natural rate of growth $\left(g_{n}\right)$, composed of the sum of labour-force growth and the rate of technical progress, each of them assumed to be exogenous.

$$
g=g_{n}
$$

Finally, in the neoclassical model, investment is identically equal to saving. It is thus the saving decisions of the households which determine investment of the firms, and the saving rate thus determines the rate of capital accumulation $(g)$ :

$$
\sigma=\frac{S}{p K} \equiv g=\frac{p I}{p K} .
$$

Equation (6n) is what Harrod (1939) used to call the 'warranted rate of growth'. In the neoclassical model, the warranted rate of growth will now adjust towards the natural rate of growth through a variation in the capital-potential-output ratio.

Graphically, the old neoclassical growth model is presented in Figure 1. On the right-hand side, we have the relationship between the rate of profit and the saving rate (equation (2)), the latter being identical to the rate of capital accumulation (equation (6n)). On the left-hand side, we have the relationship between the rate of profit and the capital-potential-output ratio (equation (1)), assuming the profit share to be given technologically and capacity utilisation at its normal rate. In long-run growth equilibrium, the natural rate of growth determines the equilibrium growth rate of capital accumulation (the warranted rate), and with a given propensity to save thus the equilibrium rate of profit. The latter will adjust to its equilibrium rate through changes in the capital-potential-output ratio, that is, through substitution between capital and labour guided by flexible real wages and real interest rates in the labour and capital markets, responding to changes in factor supply and demand. 


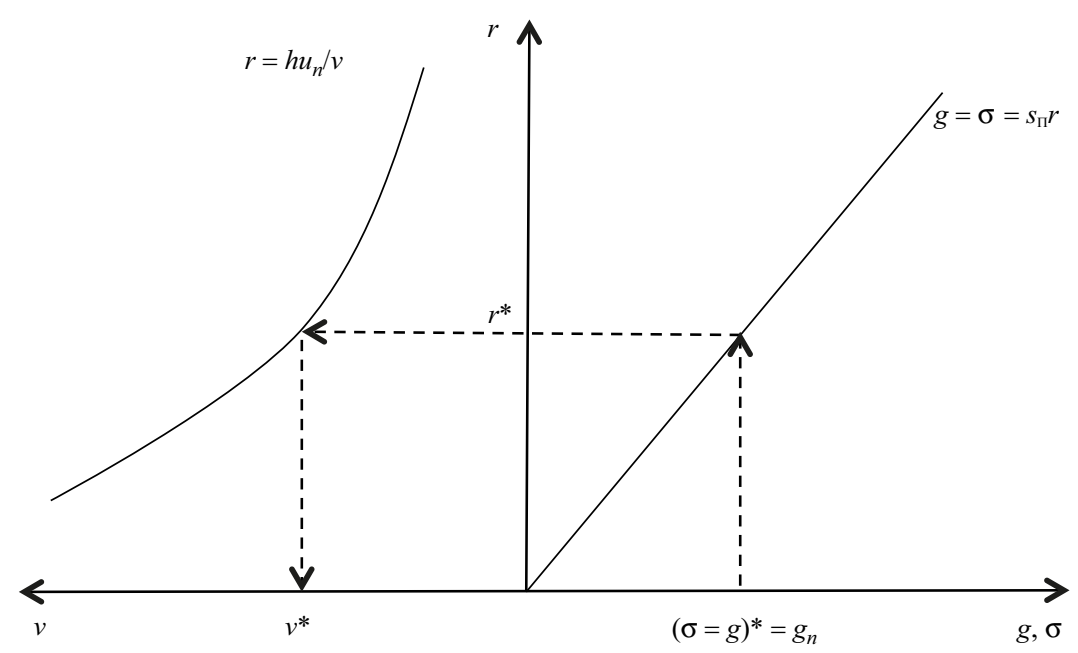

Figure 1 The old neoclassical growth theory

With the natural rate of growth as an exogenous variable, together with the propensity to save out of profits (determined by time preference in more elaborated models), the profit share (given by production technology) and the normal rate of utilisation (determined by technology), the warranted rate of growth, the rate of profit and the capital-potential-output ratio become the endogenous variables in the old neoclassical growth model (Table 1). A higher (lower) natural rate of growth will cause a higher (lower) warranted rate of growth, a higher (lower) rate of profit and a lower (higher) capital-potential-output ratio. A higher (lower) propensity to save out of profits, and thus a clockwise (counter-clockwise) rotation of the $g$ - $\sigma$-curve, will have no effect on the equilibrium rates of growth and capital accumulation, but will cause a lower (higher) rate of profit and a higher (lower) capital-potential-output ratio. Finally, a higher (lower) profit share or a higher (lower) normal rate of utilisation - through a change in production technology - and thus an upwards (downwards) shift of the $r$-curve in Figure 1, will have no effect on the equilibrium rates of growth and capital accumulation, but will cause a higher (lower) capital-potential-output ratio.

\subsection{The new neoclassical closure}

Turning to the new neoclassical growth models inspired by Romer (1986) and Lucas (1988) we obtain the following closure. As in the old neoclassical growth model, utilisation of the capital stock in long equilibrium is at its optimal, target or normal level and labour is fully employed, too:

$$
u=u_{n} .
$$

Factor income shares and thus the profit share are again given by production technology, assuming marginal productivity remuneration:

$$
h=\bar{h} \text {. }
$$

But different from the old neoclassical growth model, the capital-potential-output ratio is no longer a passively adjusting variable. It is now a constant, either determined by 
226 Review of Keynesian Economics, Vol. 5 No. 2

Table 1 Effects of changes in exogenous variables on endogenous variables in different distribution and growth theories

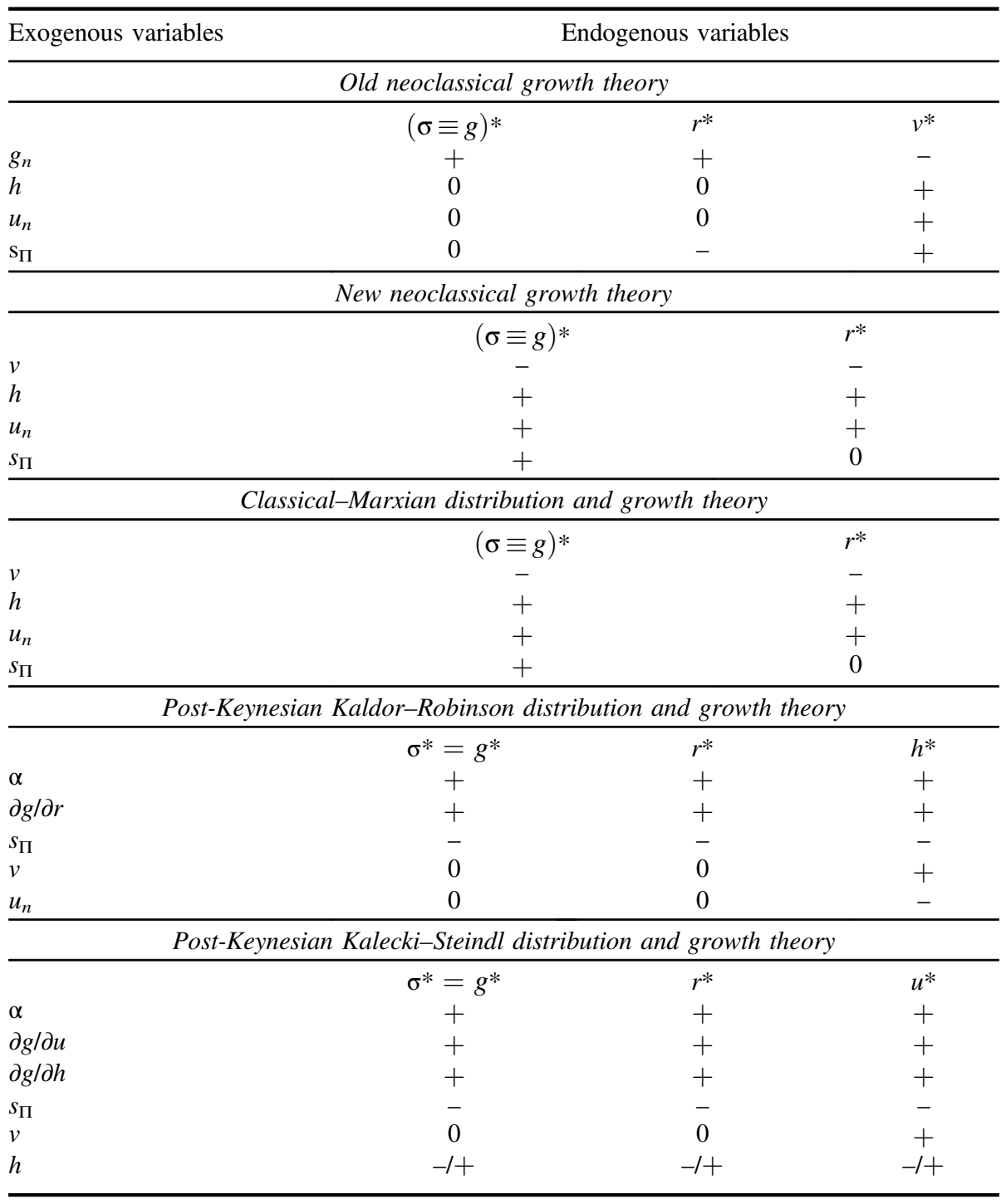

macroeconomic externalities exactly compensating for falling marginal productivities at microeconomic levels, as in the AK model, or by productivity growth generated by human capital or $R \& D$ expenditures in the respective models compensating for falling marginal productivities. Taking the AK model as the most simple, workhorse model of new neoclassical growth theory, with a production function $Y=A K$, and $A$ as constant (broad) capital productivity (Hein 2014, ch. 3, sec. 5), we obtain:

$$
v=\frac{1}{A} \text {. }
$$




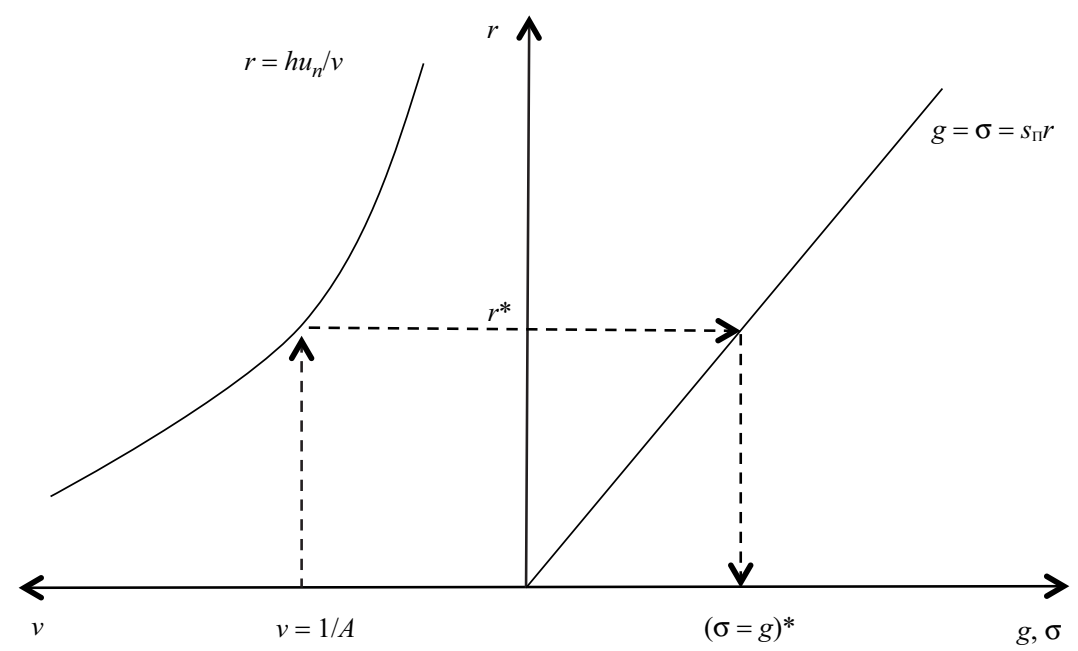

Figure 2 The new neoclassical growth theory

Finally, as in the old neoclassical growth model, investment is identically equal to saving:

$$
\sigma=\frac{S}{p K} \equiv g=\frac{p I}{p K} \text {. }
$$

Figure 2 presents the new neoclassical growth theory, using the same equations as for the old neoclassical model, but now the causality has turned around. The capital-potentialoutput ratio turns out to be the exogenous variable in our model set-up, itself determined by externalities or by technology and preferences with respect to the generation of technological progress through human capital accumulation or R\&D expenditures. The other exogenous variables are again the propensity to save out of profits (determined by time preference), the profit share and the normal rate of utilisation (each determined by technology). The endogenous variables are now the rate of profit and the rates of accumulation and growth (Table 1). A higher (lower) broad capital productivity and thus a lower (higher) capital-potential-output ratio cause a higher (lower) rate of profit and higher (lower) equilibrium rates of accumulation and growth. A higher (lower) profit share or a higher (lower) normal rate of utilisation, and thus an upwards (downwards) shift of the $r$-curve, have the same effects. A higher (lower) propensity to save, hence a clockwise (counter-clockwise) rotation of the $g$ - $\sigma$-curve, causes a higher (lower) equilibrium rate of capital accumulation and growth, but has no effect on the equilibrium profit rate.

\subsection{The classical-Marxian closure}

Discussing the classical and orthodox Marxian closure in our model, we have again that productive capacities given by the capital stock are used at their normal or target rate in the long-run growth equilibrium:

$$
u=u_{n} .
$$

Usually, in the classical-Marxian approach we have unemployment in the long-run growth equilibrium. Functional income distribution is determined by socio-institutional 
factors and distribution conflict - either over the real wage rate or over the rate of interest, as explained above. Let us here focus on the subsistence or conventional real wage rate $\left(w_{s}^{r}\right)$, which for a given production technology and thus a given labour-output ratio (a) determines the profit share:

$$
h=\frac{p Y-w L}{p Y}=1-w_{s}^{r} a,
$$

with $w$ representing the nominal wage rate and $L$ the labour input. If the technical conditions of production are taken as given - that is, not responding in any systematic way towards changes in distribution or economic activity - we also have:

$$
v=\bar{v} .
$$

And finally, we have the classical version of Say's law, with saving determining investment in the capital stock:

$$
\sigma=\frac{S}{p K} \equiv g=\frac{p I}{p K}
$$

Figure 3 presents the classical-Marxian distribution and growth model. On the righthand side, we have the relationship between the rate of profit and the saving and accumulation rate from equations $(2)$ and $(6 \mathrm{~cm})$. And on the left-hand side, we have the rate of profit from equation (1), for a given capital-potential-output ratio and normal rate of capacity utilisation only depending on the profit share. Distribution conflict determines the profit share, thus the profit rate, and the latter, together with the propensity to save out of profits, determines equilibrium capital accumulation and growth.

The exogenous variables in the classical-Marxian model are thus the profit share, the capital-potential-output ratio, the normal rate of capacity utilisation and the propensity to save out of profits (Table 1). A higher (lower) profit share, as well as a higher (lower) normal rate of utilisation, the latter through a clockwise (counter-clockwise)

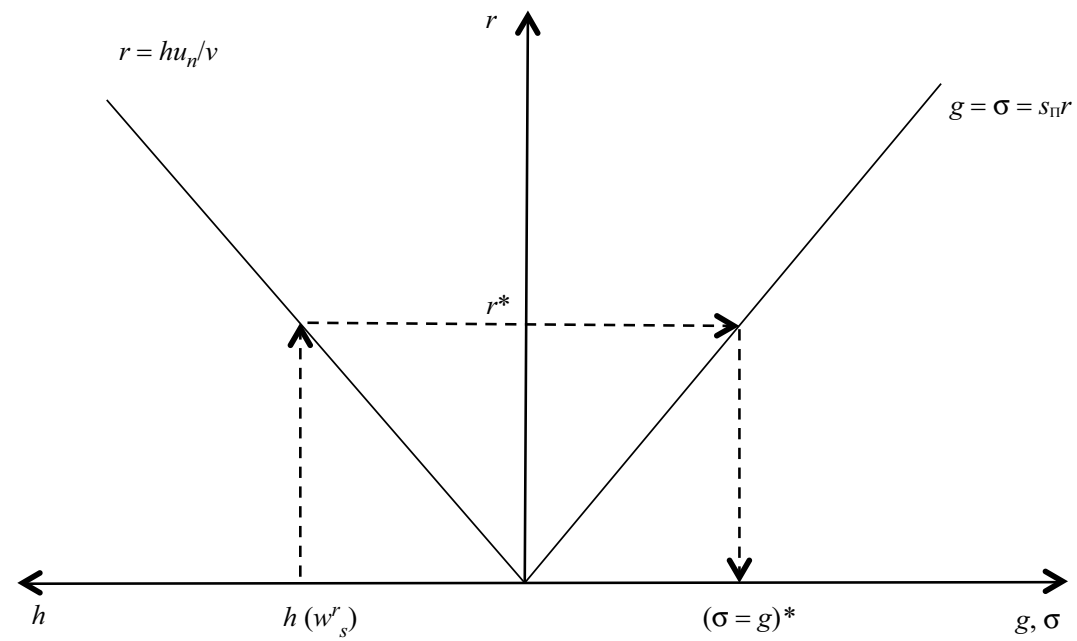

Figure 3 The classical-Marxian distribution and growth theory 
rotation of the $r$-curve will cause a higher (lower) profit rate and a higher (lower) equilibrium rate of capital accumulation and growth. Technical change triggering a higher (lower) capital-potential-output ratio, hence a counter-clockwise (clockwise) rotation of the $r$-curve, will lead to a lower (higher) rate of profit and thus also to lower (higher) equilibrium capital accumulation and growth, as in Marx's (1894) falling rate of profit and overaccumulation crisis theory. Finally, a higher (lower) propensity to save, hence a clockwise (counter-clockwise) rotation of the $g$ - $\sigma$-curve, will cause a higher (lower) equilibrium rate of accumulation and growth, but will have no effect on the equilibrium profit rate. These results are structurally similar to the ones in the new neoclassical growth theory - although based on a very different type of model - as already acknowledged by Kurz and Salvadori's (2003) article.

\subsection{The post-Keynesian Kaldor-Robinson closure}

The textbook version of the first generation post-Keynesian distribution and growth model in the tradition of Kaldor and Robinson (Hein 2014, ch. 4, sec. 4; Lavoie 2014 , ch. 6 , sec. 1) provides the following closure. In the long-run growth equilibrium, the utilisation of productive capacities given by the capital stock is at its normal or target rate:

$$
u=u_{n} .
$$

Labour, however, is usually not fully employed. The capital-potential-output ratio is an exogenous variable, which is itself affected by the nature of technical progress. However, it is not systematically related to the rate of profit or economic activity:

$$
v=\bar{v} \text {. }
$$

With a constant and given normal rate of utilisation and a given capital-potential-output ratio, the profit share becomes the variable adjusting the profit rate (equation (1)) to its equilibrium value. The distinguishing feature of the post-Keynesian approach, as mentioned above, is the independence of firms' investment decisions from households' saving decisions. This means that we now have an investment function separately from the saving function in equation (2):

$$
g=g(\alpha, r), \quad \frac{\partial g}{\partial \alpha}>0, \frac{\partial g}{\partial r}>0 .
$$

Following Kaldor (1957; 1961) and Robinson (1956; 1962), investment decisions are determined by firms' 'animal spirits' $(\alpha)$, describing the 'spontaneous urge to action rather than inaction' (Keynes 1936 [1973], p. 161), and by the (expected) rate of profit. Profits and thus the profit rate are considered to have a positive influence on investment decisions, as retained profits provide internal funds for investment, and furthermore they alleviate the access of firms to external funds in incompletely competitive financial markets. Equation (6kr) is the goods market equilibrium, in which the accumulation rate and the saving rate have to be equal:

$$
g^{*}=\frac{p I}{p K}=\sigma^{*}=\frac{S}{p K} .
$$

The full Kaldor-Robinson distribution and growth model is presented in Figure 4. On the right-hand side, we have the accumulation rate and the saving rate, each as a function of the rate of profit. And on the left-hand side, we have the relationship of the profit rate 


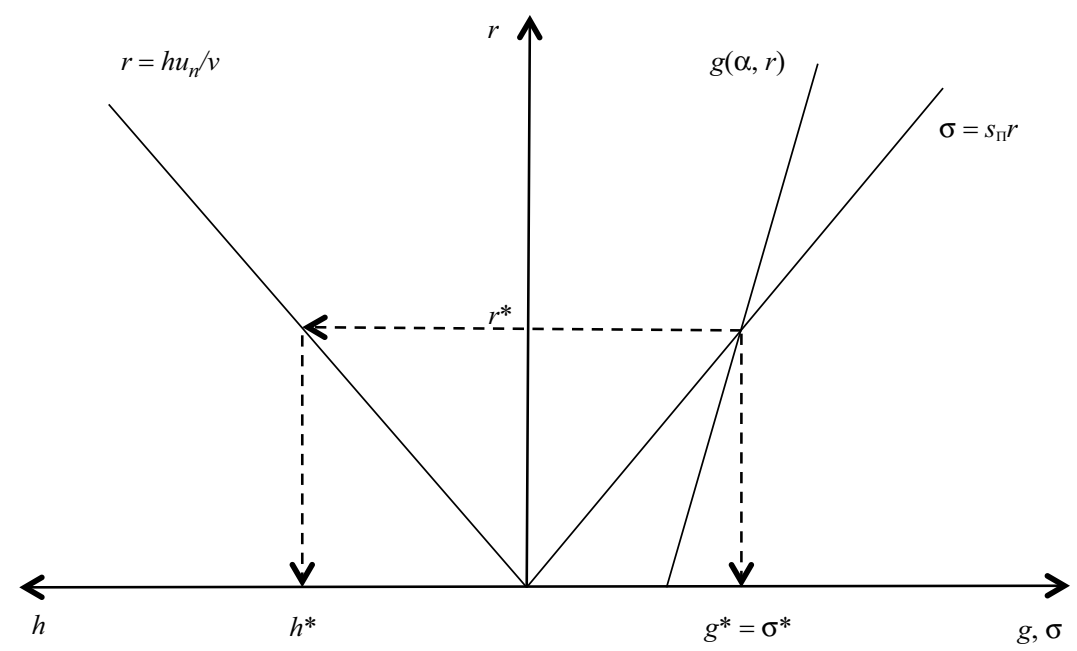

Figure 4 The post-Keynesian Kaldor-Robinson distribution and growth theory

and the profit share for a given normal rate of capacity utilisation and a given capitalpotential-output ratio. The point of intersection of investment and saving functions determines the long-run equilibrium accumulation and growth rate, as well as the associated equilibrium profit rate, with the profit share as the adjusting variable. Higher equilibrium growth will trigger a higher profit rate, a higher profit share and thus a lower wage share.

In the post-Keynesian Kaldor-Robinson model, we have as exogenous variables and parameters those determining the investment and saving function, which are animal spirits, the responsiveness of investment with respect to the profit rate $(\partial g / \partial r)$, and the propensity to save out of profits, as well as the exogenous and given normal rate of utilisation and capital-potential-output ratio (Table 1). Any rise (fall) in animal spirits, hence a rightwards (leftwards) shift in the $g$-curve, or in the responsiveness of investment to the profit rate, hence a clockwise (counter-clockwise) rotation in the $g$-curve, will cause higher (lower) equilibrium rates of accumulation, growth and profit, and a higher (lower) profit share. A higher (lower) propensity to save, thus a clockwise (counter-clockwise) rotation in the $\sigma$-curve, has a negative (positive) effect on the equilibrium values of accumulation, growth, the profit rate and the profit share. The paradox of thrift is thus valid for long-run growth, too. Finally, any change in the capital-potential-output ratio or in the normal rate of utilisation will have no effects on the equilibrium accumulation, growth and profit rates, but will only affect the equilibrium profit share. A change in the capital-potentialoutput ratio (rotation in the $r$-curve) will be positively related with the profit share, whereas a change in the normal rate of utilisation (rotation in the $r$-curve, too) will have an inverse effect on the profit share.

\subsection{The post-Keynesian Kalecki-Steindl closure}

The final closure to be discussed is the one based on the contributions by Kalecki (1954; 1971) and Steindl (1952), and included in the textbook version of the neoKaleckian and post-Kaleckian models (Blecker 2002; Hein 2014, ch. 6; Lavoie 2014, ch. 6, sec. 2). As explained above, the rate of capacity utilisation becomes an 
endogenous variable in the Kalecki-Steindl approach. The profit share, and thus the functional income distribution, is mainly determined by the mark-up in firms' pricing in imperfectly competitive markets. In our simple closed private one-good economy model, it is thus only the mark-up $(m)$ on constant unit labour costs which determines the profit share:

$$
h=h(\bar{m}), \quad \frac{\partial h}{\partial m}>0
$$

The mark-up itself is affected by several factors, as the degree of competition in the goods market and the bargaining power of workers, which we all treat as constant and given. The capital-potential-output ratio is also considered as an exogenous variable determined by technology, which does not systematically respond to distribution and activity variables in the model:

$$
v=\bar{v}
$$

With the profit share and the capital-potential-output ratio as exogenously given, the rate of capacity utilisation becomes the variable adjusting the profit rate (equation (1)) to its equilibrium value. The determinants in the Kalecki-Steindl investment function are basically similar to the ones in the Kaldor-Robinson model. We again have firms' or managements' animal spirits $(\alpha)$, sometimes taken to represent the firms' assessment of the long-run growth trend of the economy. Furthermore, the (expected) rate of profit is of relevance, because it indicates internal means of finance required for external investment finance, according to Kalecki's (1937) 'principle of increasing risk'. Also the dynamics of demand are reflected in the rate of profit through changes in capacity utilisation (equation (1)). Different from the KaldorRobinson model, however, Kaleckians and Steindlians prefer to include the constituting elements of the profit rate into the investment function, because, as Bhaduri and Marglin (1990) in particular have argued, the source of a change in the profit rate may be important when it comes to the discussion of the effects on firms' investment decisions. Therefore, on top of animal spirits we have included the three principle determinants of the profit rate from equation (1) into the Kalecki-Steindl accumulation function:

$$
g=g(\alpha, h, u, v), \quad \frac{\partial g}{\partial \alpha}>0, \frac{\partial g}{\partial h} \geq 0, \frac{\partial g}{\partial u}>0, \frac{\partial g}{\partial v}=0 .
$$

Investment decisions will thus positively depend on the profit share and the rate of capacity utilisation, because each will increase the (expected) rate of profit, ceteris paribus. Here, it is important to understand that we are talking about partial effects on investment decisions, applying the ceteris paribus clause, and are not yet considering the further feedback effects through the model. However, neo-Kaleckians would insist that even the partial effect of a change in the profit share is irrelevant for firms' decisions to invest, and hence that $\partial g / \partial h=0$. Regarding changes in the capital-potential-output ratio through technical change, the partial effects on investment decisions are not clear. On the one hand, a higher capital-potential-output ratio means a lower rate of profit which should dampen investment. On the other hand, however, a higher capital-potential-output ratio means that a certain increase in demand requires a higher increase in the capital stock than before, which should boost investment. The sign of the sum of these two 


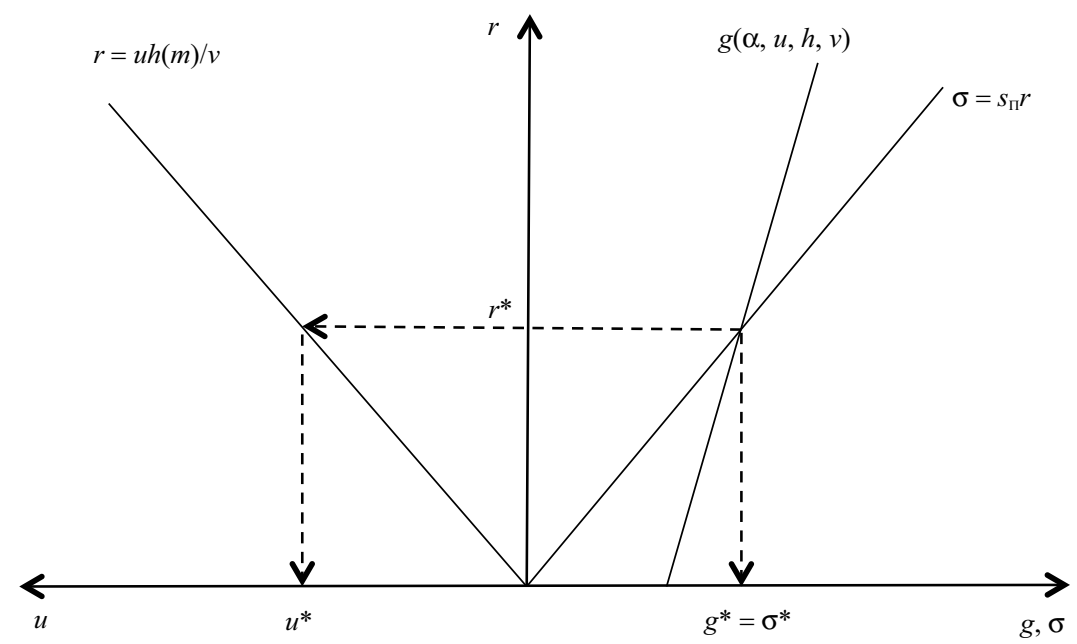

Figure 5 The post-Keynesian Kalecki-Steindl distribution and growth theory

opposing effects is not clear ex ante, so that we will disregard any direct effect of changes in the capital-potential-output ratio on investment in what follows. Finally, equation (6ks) is again the familiar goods market equilibrium condition:

$$
g^{*}=\frac{p I}{p K}=\sigma^{*}=\frac{S}{p K} .
$$

Figure 5 presents the general post-Keynesian Kalecki-Steindl distribution and growth model. On the right-hand side, we have the accumulation rate and the saving rate, each as a function of the rate of profit - bearing in mind that we have to take into account potentially different effects of the components of the profit rate on investment. And on the left-hand side we have the relationship of the profit rate with the rate of capacity utilisation, for a given profit share and a given capital-potential-output ratio. The point of intersection of investment and saving functions determines the long-run equilibrium accumulation and growth rate, as well as the associated equilibrium profit rate, with capacity utilisation as the adjusting variable. Higher equilibrium growth will trigger a higher profit rate and a higher equilibrium rate of utilisation. Higher growth will thus not come at the expense of the workers' share in national income, which will remain constant, as long as the determinants of the mark-up do not change. ${ }^{9}$

In the Kalecki-Steindl approach, we have again the parameters and coefficients of the saving and investment functions as exogenous variables: animal spirits, the responsiveness of investment with respect to capacity utilisation $(\partial g / \partial u)$ and with respect to the profit share $(\partial g / \partial h$, which is zero in the neo-Kaleckian model), and the propensity to save out of profits (Table 1). Furthermore, we have the capital-potential-output

9. Obviously, here we could now discuss feedback effects of economic activity on income distribution through changes in the degree of competition, workers' bargaining power or other channels. However, this would go beyond our simple overview. See Dutt (2012) for a detailed review and discussion, as well as Stockhammer (2004), Lavoie (2010), Hein and Stockhammer (2011) and Assous and Dutt (2013), among several others, for modelling attempts. 
ratio, a change of which will only affect the relationship between the equilibrium profit rate and the utilisation rate, because we have disregarded any unique direct effect on investment. And finally, we have the profit share, which will affect the left-hand side of Figure 5, but potentially also the right-hand side through the effects on capital accumulation. Any rise (fall) in animal spirits, hence a rightwards (leftwards) shift in the $g$-curve, or in the responsiveness of investment with respect to capacity utilisation or the profit share, thus a clockwise (counter-clockwise) rotation in the $g$-curve, will cause higher (lower) equilibrium rates of accumulation, growth, profit and capacity utilisation. A higher (lower) propensity to save out of profits, thus a clockwise (counter-clockwise) rotation in the $\sigma$-curve, will cause lower (higher) equilibrium rates of accumulation, growth, profit and capacity utilisation - the paradox of thrift again. A change in the capital-potential-output ratio will only have positive effects on equilibrium capacity utilisation, through a rotation in the $r$-curve, but will have no effects on the equilibrium rates of accumulation and profit. Finally, changes in the profit share will either have positive or negative effects on the equilibrium rates of capital accumulation, growth and profit, depending on whether we apply the neo- or the post-Kaleckian approach towards the determinants of investment, as we will analyse graphically in more detail now.

Any change in the profit share will affect both the $r$-curve and potentially the $g$-curve in our Kalecki-Steindl model. On the one hand, a higher (lower) profit share will cause a clockwise (counter-clockwise) rotation of the $r$-curve in Figure 5. On the other hand, a higher (lower) profit share will cause a rotation of the $g$-curve, if $\partial g / \partial h>0$. Here the direction will depend on the relative importance of the profit share and the rate of utilisation in the investment function. Let us focus on a reduction of the profit share in what follows, caused by a reduction in the mark-up; for an increase in the mark-up and the profit share, the arguments below apply in reverse.

With a strong responsiveness of investment towards utilisation $(\partial g / \partial u)$ and a very weak or even zero reaction towards the profit share $(\partial g / \partial h)$, as assumed in the neoKaleckian model, a fall in the profit share and thus a lower profit share and a higher rate of utilisation for every rate of profit, hence a counter-clockwise rotation of the $r$-curve, will also trigger a clockwise rotation of the $g$-curve in $g$-r-space, as shown in Figure 6. Every rate of profit will be associated with a higher rate of utilisation, and firms' investment will respond accordingly. This will then cause higher equilibrium rates of accumulation, growth, profit and capacity utilisation. The economy will be in a wage-led demand and a wage-led growth regime, or, as Bhaduri and Marglin (1990) term it, in a stagnationist demand and wage-led growth regime. Furthermore, the paradox of costs (Rowthorn 1981) applies: a higher wage share triggers a higher profit rate.

However, the wage-led demand/wage-led growth regime is only one possible regime, if we consider a positive and somewhat stronger effect of the profit share on capital accumulation, as has been argued by Bhaduri and Marglin (1990). In this case a lower profit share, triggering a higher rate of utilisation for every profit rate, hence the counter-clockwise rotation of the $r$-curve, will be associated with a counter-clockwise rotation of the $g$-curve, too. Each rate of profit is associated with a lower profit share, and firms will accumulate at a lower rate. If this rotation of the $g$-curve is not too pronounced, we may still get wage-led demand, hence higher equilibrium utilisation, but profit-led growth, thus lower equilibrium capital accumulation and growth. Furthermore, the equilibrium profit rate comes down, too, and the paradox of costs disappears. Bhaduri and Marglin (1990) call this a 'stagnationist conflict' or a 'profit squeeze' constellation: although redistribution in favour of wages is expansionary with respect to aggregate demand and capacity utilisation, it will not be supported 


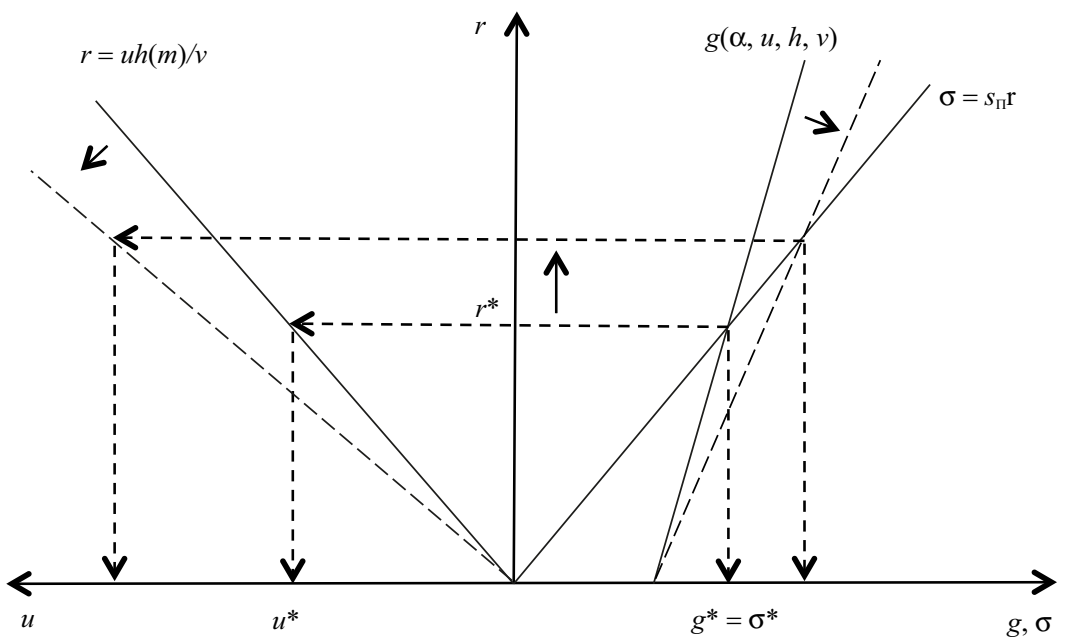

Figure 6 A reduction in the profit share in the Kalecki-Steindl growth theory: the neo-Kaleckian model and the wage-led demand/wage-led growth regime of the post-Kaleckian model

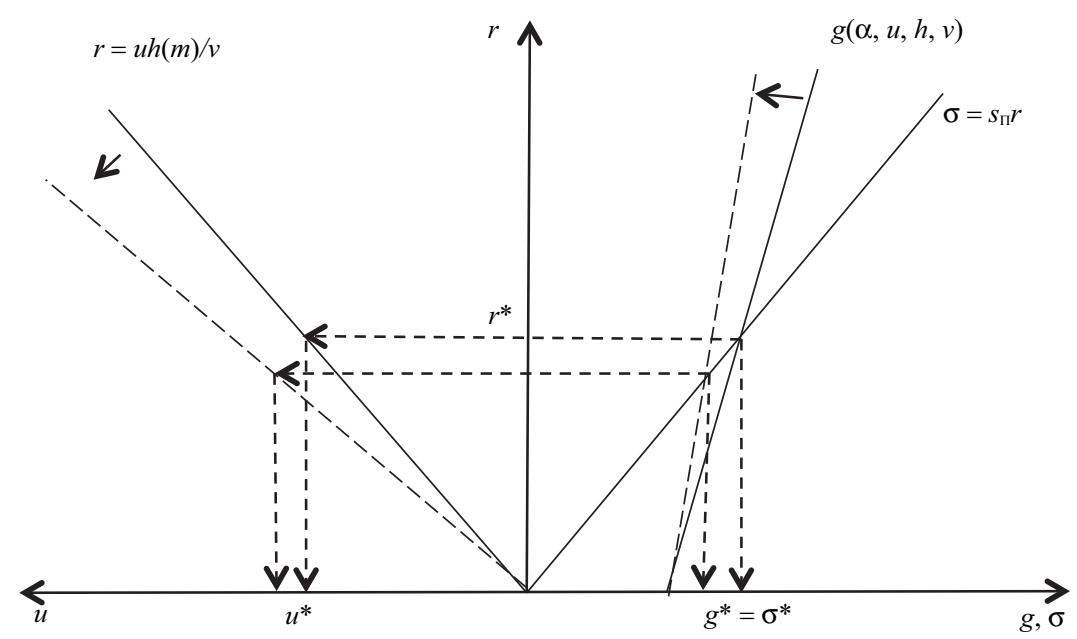

Figure 7 A reduction in the profit share in the Kalecki-Steindl growth theory: the intermediate case with wage-led demand and profit-led growth in the post-Kaleckian model

by capitalists, because it will mean a lower rate of profit to them and also a lower rate of accumulation and growth. Figure 7 shows this intermediate case.

Finally, if the effect of the profit share on investment is very pronounced, a lower profit share will cause a more considerable counter-clockwise rotation of the $g$-curve, as in Figure 8, and we will see profit-led demand and profit-led growth. A lower profit share will thus cause lower equilibrium rates of capacity utilisation, capital accumulation, growth and profit. Bhaduri and Marglin (1990) call this an exhilarationist demand and a 


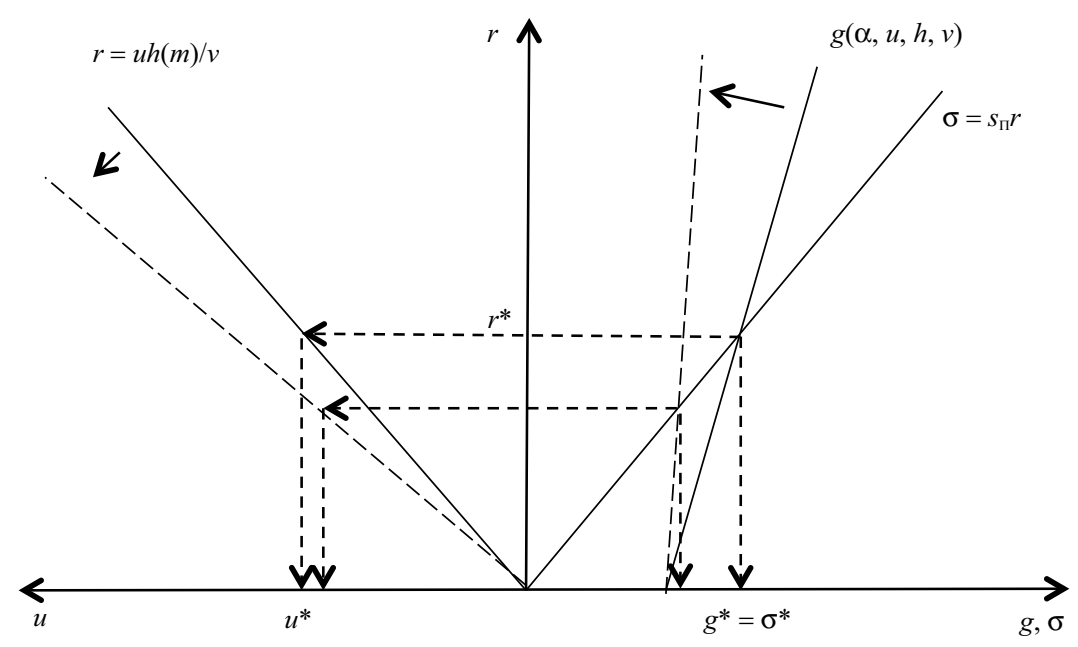

Figure 8 A reduction in the profit share in the Kalecki-Steindl growth theory: the profit-led demand and profit-led growth regime in the post-Kaleckian model

profit-led growth regime. The model generates basically the same results as the classical-Marxian and the new neoclassical growth theories, but here in a demand-led growth framework without having to assume Say's law.

In our graphical derivation of the potential regimes in the post-Kaleckian framework, we have focused on the relative responsiveness of capital accumulation towards the rate of capacity utilisation and the profit share. It should be added that the regimes will also depend on the propensity to save out of profits, which determines the slope of the $\sigma$-curve. As can easily be checked graphically, the higher the propensity to save out of profits, the more likely are wage-led regimes in the face of redistribution of income, and vice versa.

With the three potential regimes, we have demonstrated that the post-Kaleckian model closure provides a very flexible instrument. It allows for the derivation of different demand and growth regimes depending on model parameter values, and thus encompasses several of the approaches discussed in this section - from the new growth theory and the classical-Marxian approach generating profit-led growth to the neo-Kaleckian wage-led demand and growth models, with an intermediate regime of wage-led demand and profit-led growth in between.

\section{SUMMARY AND CONCLUSIONS}

Starting from a review of the main strands of orthodox and heterodox distribution and growth models and their distinguishing features, with the post-Kaleckian Bhaduri and Marglin (1990) (and Kurz 1990) model as a specific but highly flexible variant of heterodox distribution and growth theories, we have developed a simple modelling framework in which we could treat these different theories as different variants of model closure. This has allowed for a systematic comparison of exogenous and endogenous variables, of the 'logic' or the chain of causalities in each of the approaches, 
and of the generation of the long-run equilibrium positions of the system. This method has also generated close similarities in this respect, based on very different model foundations and assumptions, as for example between the new neoclassical growth theory and the classical-Marxian approach. Finally, we have vindicated in this framework, too, Bhaduri and Marglin's (1990) claim that their modelling framework provides a very flexible tool, based on the notion of distributional struggle and the principle of effective demand, which allows for the derivation of different demand and growth regimes, and thus encompasses several of the approaches discussed in this framework - from the profit-led growth approach of the new growth theory and the classical-Marxian model to the neo-Kaleckian wage-led demand and growth model, with an intermediate regime of wage-led demand and profit-led growth in between.

\section{REFERENCES}

Aghion, P. and P. Howitt (2009), The Economics of Growth, Cambridge, MA: MIT Press.

Amadeo, E.J. (1986), 'Notes on capacity utilisation, distribution and accumulation', Contributions to Political Economy, 5, 83-94.

Argitis, G. (2001), 'Intra-capitalists' conflict, monetary policy and income distribution', Review of Political Economy, 13, 453-470.

Assous, M. and A.K. Dutt (2013), 'Growth and income distribution with the dynamics of power in labour and goods markets', Cambridge Journal of Economics, 37, 1407-1430.

Barro, R.J. and X. Sala-i-Martin (2004), Economic Growth, 2nd edn, Cambridge, MA: MIT Press.

Bhaduri, A. and S. Marglin (1990), 'Unemployment and the real wage: the economic basis for contesting political ideologies', Cambridge Journal of Economics, 14, 375-393.

Blecker, R.A. (1989), 'International competition, income distribution and economic growth', Cambridge Journal of Economics, 13, 395-412.

Blecker, R.A. (2002), 'Distribution, demand and growth in neo-Kaleckian macro-models', in M. Setterfield (ed.), The Economics of Demand-Led Growth, Cheltenham, UK and Northampton, MA: Edward Elgar, pp. 129-152.

Blecker, R.A. (2016), 'Wage-led versus profit-led demand regimes: the long and the short of it', Review of Keynesian Economics, 4(4), 373-390.

Bowles, S. and R. Boyer (1995), 'Wages, aggregate demand, and employment in an open economy: an empirical investigation', in G.A. Epstein and H.M. Gintis (eds), Macroeconomic Policy after the Conservative Era, Cambridge, UK: Cambridge University Press, pp. 143-171.

Clark, J.B. (1899), The Distribution of Wealth: A Theory of Wages, Interest and Profits, New York: Macmillan (reprint, New York: Cosimo, 2005).

Dutt, A.K. (1984), 'Stagnation, income distribution and monopoly power', Cambridge Journal of Economics, 8, 25-40.

Dutt, A.K. (1987), 'Alternative closures again: a comment on "Growth, distribution and inflation", Cambridge Journal of Economics, 11, 75-82.

Dutt, A.K. (1990), Growth, Distribution and Uneven Development, Cambridge, UK: Cambridge University Press.

Dutt, A.K. (2012), 'Distributional dynamics in Post Keynesian growth models', Journal of Post Keynesian Economics, 34, 431-451.

Harcourt, G.C. (1969), 'Some Cambridge controversies in the theory of capital', Journal of Economic Literature, 7, 369-405.

Harris, D.J. (1987), 'Classical growth models', in J. Eatwell, M. Milgate and P. Newman (eds), The New Palgrave: A Dictionary of Economics, Vol. 1, London, New York and Tokyo: Palgrave Macmillan, pp. 445-448.

Harrod, R.F. (1939), 'An essay in dynamic theory', The Economic Journal, 49, 14-33.

Hartwig, J. (2014), 'Testing the Bhaduri-Marglin model with OECD panel data', International Review of Applied Economics, 28, 419-435. 
Hein, E. (2006), 'Money, interest and capital accumulation in Karl Marx's economics: a monetary interpretation and some similarities to post-Keynesian approaches', European Journal of the History of Economic Thought, 13, 113-140.

Hein, E. (2014), Distribution and Growth after Keynes: A Post-Keynesian Guide, Cheltenham, UK and Northampton, MA: Edward Elgar.

Hein, E. and E. Stockhammer (2011), 'A post-Keynesian macroeconomic model of inflation, distribution and employment', in E. Hein and E. Stockhammer (eds), A Modern Guide to Keynesian Macroeconomics and Economic Policies, Cheltenham, UK and Northampton, MA: Edward Elgar, pp. 112-136.

Hein, E., M. Lavoie and T. van Treeck (2011), 'Some instability puzzles in Kaleckian models of growth and distribution: a critical survey', Cambridge Journal of Economics, 35, 587-612.

Hein, E., M. Lavoie and T. van Treeck (2012), 'Harrodian instability and the "normal rate" of capacity utilisation in Kaleckian models of distribution and growth - a survey', Metroeconomica, 63, 139-169.

Kaldor, N. (1957), 'A model of economic growth', The Economic Journal, 67, 591-624 (reprinted in N. Kaldor, Collected Economic Essays, Volume 2, Essays on Economic Stability and Growth, London: Duckworth, 1960).

Kaldor, N. (1961), 'Capital accumulation and economic growth', in F.A. Lutz and D.C. Hague (eds), The Theory of Capital, London: Macmillan (reprinted in N. Kaldor, Collected Economic Essays, Volume 5, Further Essays on Economic Theory, London: Duckworth, 1978, pp. 177-222).

Kaldor, N. (1966), Causes of the Slow Rate of Economic Growth in the United Kingdom, Cambridge, UK: Cambridge University Press (reprinted in N. Kaldor, Collected Economic Essays, Volume 5, Further Essays on Economic Theory, London: Duckworth, 1978).

Kalecki, M. (1937), 'The principle of increasing risk', Economica, 4, 440-447.

Kalecki, M. (1939), Essays in the Theory of Economic Fluctuations, London: George Allen and Unwin.

Kalecki, M. (1954), Theory of Economic Dynamics, London: George Allen and Unwin.

Kalecki, M. (1969), Studies in the Theory of the Business Cycle, 1933-1939, Oxford: Basil Blackwell.

Kalecki, M. (1971), Selected Essays on the Dynamics of the Capitalist Economy, 1933-70, Cambridge, UK: Cambridge University Press.

Keynes, J.M. (1936 [1973]), The General Theory of Employment, Interest, and Money, in The Collected Writings of J.M. Keynes, Vol. VII, London and Basingstoke, UK: Macmillan.

Kurz, H.D. (1990), 'Technical change, growth and distribution: a steady-state approach to "unsteady" growth', in H.D. Kurz, Capital, Distribution and Effective Demand, Cambridge, UK: Polity Press, pp. 210-239.

Kurz, H.D. and N. Salvadori (2003), 'Theories of economic growth: old and new', in N. Salvadori (ed.), The Theory of Economic Growth: A 'Classical' Perspective, Cheltenham, UK and Northampton, MA: Edward Elgar, pp. 1-22.

Lavoie, M. (2010), 'Surveying long-run and short-run stability issues with the Kaleckian model of growth', in M. Setterfield (ed.), Handbook of Alternative Theories of Economic Growth, Cheltenham, UK and Northampton, MA: Edward Elgar, pp. 132-156.

Lavoie, M. (2014), Post-Keynesian Economics: New Foundations, Cheltenham, UK and Northampton, MA: Edward Elgar.

Lazzarini, A. (2011), Revisiting the Cambridge Capital Controversies: A Historical and Analytical Study, Pavia: Pavia University Press.

Lucas, R.E. (1988), 'On the mechanics of economic development', Journal of Monetary Economics, 22, 3-42.

Marglin, S.A. (1984a), Growth, Distribution and Prices, Cambridge, MA: Harvard University Press.

Marglin, S.A. (1984b), 'Growth, distribution and inflation: a centennial synthesis', Cambridge Journal of Economics, 8, 115-144.

Marx, K. (1867), Das Kapital. Kritik der politischen Ökonomie, Erster Band: Der Produktionsprozeß des Kapitals, 4th edn 1890, edited by F. Engels (reprinted as MarxEngels-Werke, Volume 23, Berlin: Dietz Verlag 1962, English translation: Capital. A Critique 
of Political Economy, Volume 1: The Process of Capitalist Production, New York: International Publisher, 1967).

Marx, K. (1885), Das Kapital. Kritik der politischen Ökonomie, Zweiter Band: Der Zirkulationsprozeß des Kapitals, 2nd edition 1893, edited by F. Engels (reprinted as Marx-Engels-Werke, Volume 24, Berlin: Dietz Verlag 1963, English translation: Capital. A Critique of Political Economy, Volume 2: The Process of Circulation of Capital, New York: International Publisher, 1967).

Marx, K. (1894), Das Kapital. Kritik der politischen Ökonomie, Dritter Band: Der Gesamtprozeß der kapitalistischen Produktion, edited by F. Engels (reprinted as MarxEngels-Werke, Volume 25, Berlin: Dietz Verlag 1964, English translation: Capital. A Critique of Political Economy, Volume 3: The Process of Capitalist Production as a Whole, New York: International Publisher, 1967).

Onaran, Ö. and G. Galanis (2014), 'Income distribution and growth: a global model', Environment and Planning A, 46, 2489-2513.

Panico, C. (1985), 'Market forces and the relation between the rate of interest and profit', Contributions to Political Economy, 4, 37-60.

Pasinetti, L.L. (1974), Growth and Income Distribution: Essays in Economic Theory, Cambridge, UK: Cambridge University Press.

Pivetti, M. (1991), An Essay on Money and Distribution, Basingstoke and London: Macmillan.

Ricardo, D. (1817 [1951]), On the Principles of Political Economy and Taxation: The Works and Correspondence of David Ricardo, Vol. I., edited by P. Sraffa, Cambridge, UK: Cambridge University Press.

Robinson, J. (1956), The Accumulation of Capital, London: Macmillan.

Robinson, J. (1962), Essays in the Theory of Economic Growth, London: Macmillan.

Romer, P.M. (1986), 'Increasing returns and long-run growth', Journal of Political Economy, 94, 1002-1037.

Rowthorn, R.E. (1981), 'Demand, real wages and economic growth', Thames Papers in Political Economy, Autumn, 1-39.

Sen, A. (1963), 'Neo-classical and neo-Keynesian theories of distribution', Economic Record, 39, 53-64.

Shaikh, A. (1978), 'An introduction to the history of crisis theories', Union for Radical Political Economics (ed.), U.S. Capitalism in Crisis, New York: URPE, pp. 219-241.

Smith, A. (1776 [1976]), An Inquiry into the Nature and Causes of the Wealth of Nations, The Glasgow Edition of the Works and Correspondence of Adam Smith, edited by R.H. Campbell, A.S. Skinner and W.B. Todd, Oxford: Oxford University Press.

Solow, R.M. (1956), 'A contribution to the theory of economic growth', Quarterly Journal of Economics, 70, 65-94.

Sowell, T. (1972), Say's Law: An Historical Analysis, Princeton, NJ: Princeton University Press.

Sraffa, P. (1960), Production of Commodities by Means of Commodities: A Prelude to a Critique of Political Economy, Cambridge, UK: Cambridge University Press.

Steindl, J. (1952 [1976]), Maturity and Stagnation in American Capitalism, Oxford: Blackwell, 2nd edn, New York and London: Monthly Review Press.

Stockhammer, E. (2004), 'Is there an equilibrium rate of unemployment in the long run?', Review of Political Economy, 16, 59-77.

Swan, T. (1956), 'Economic growth and capital accumulation', Economic Record, 32, 334-361.

Walras, L. (1954), Elements of Pure Economics, London: Allen and Unwin (English translation of the definitive edition of Walras (1874) by W. Jaffe).

Wicksell, K. (1893), Über Wert, Kapital und Rente nach den neueren nationalökonomischen Theorien, Jena: Gustav Fischer. 